\title{
Preliminary Predictive Model of Termiticidal and Repellent Activities of Essential Oil Extracted from Ocotea quixos Leaves against Nasutitermes corniger (Isoptera: Termitidae) Using One-Factor Response Surface Methodology Design
}

\author{
Yasiel Arteaga-Crespo ${ }^{1}$ (D), Diego Ureta-Leones ${ }^{1}$, Yudel García-Quintana ${ }^{1}$, Mayra Montalván ${ }^{2}$, \\ Gianluca Gilardoni ${ }^{2}$ (D) and Omar Malagón ${ }^{2, *(D)}$ \\ 1 Facultad de Ciencias de la Tierra, Universidad Estatal Amazónica (UEA), Vía Tena Km $2 \frac{1}{2}$, Puyo, \\ Pastaza P.C. EC160150, Ecuador; yarteaga@uea.edu.ec (Y.A.-C.); diego_slade@hotmail.com (D.U.-L.); \\ ygarcia@uea.edu.ec (Y.G.-Q.) \\ 2 Departamento de Química, Universidad Técnica Particular de Loja, Calle Marcelino Champagnat s/n \\ Loja P.C. EC110107, Ecuador; msmontalvan@utpl.edu.ec (M.M.); ggilardoni@utpl.edu.ec or \\ gianluca.gilardoni@gmail.com (G.G.) \\ updates \\ * Correspondence: omalagon@utpl.edu.ec
}

Citation: Arteaga-Crespo, Y.; Ureta-Leones, D.; García-Quintana, Y.; Montalván, M.; Gilardoni, G.; Malagón, O. Preliminary Predictive Model of Termiticidal and Repellen Activities of Essential Oil Extracted from Ocotea quixos Leaves against Nasutitermes corniger (Isoptera: Termitidae) Using One-Factor Response Surface Methodology Design. Agronomy 2021, 11, 1249. https://doi.org/10.3390/ agronomy11061249

Academic Editors: Alessandra Carrubba, Mauro Sarno and Beatriz Gámiz

Received: 9 May 2021

Accepted: 18 June 2021

Published: 20 June 2021

Publisher's Note: MDPI stays neutral with regard to jurisdictional claims in published maps and institutional affiliations.

Copyright: (C) 2021 by the authors. Licensee MDPI, Basel, Switzerland This article is an open access article distributed under the terms and conditions of the Creative Commons Attribution (CC BY) license (https:// creativecommons.org/licenses/by/ $4.0 /)$

\begin{abstract}
Termites are one of the most challenging pests that agriculture and urban environments are faced with. They bring substantial losses in annual and perennial crops and damage wood components at construction sites. The development of natural products with biological activity for termite control is an ecological alternative in the search to replace conventional products. Hence, the aim of this research was to predict the termiticidal and repellent effects of the essential oil from Ocotea quixos leaves on Nasutitermes corniger using a one-factor response surface methodology design. The variable analysed was the concentration of essential oil in ethanol at an interval of $0.3-0.05 \%$ for anti-termite activity and between 0.12 and $0.01 \%$ for repellent action. A $100 \%$ mortality rate was found at concentrations higher than $0.12 \%$ and at the minimum concentration analysed, the effect was $22.2 \%$. As for the repellent action, the concentration of $0.12 \%$ was able to repel $100 \%$ of the termites and at $0.01 \%$ it repelled $48.9 \%$. The analysis of the essential oil from Ocotea quixos leaves by GC-MS resulted in the presence of 42 compounds, 39 of them elucidated. The main compounds were $(E)$-cinnamyl acetate $(36.44 \%),(E)$-cinnamaldehyde $(27.03 \%),(E)-\beta$-caryophyllene $(5.21 \%)$ and (E)-methyl isoeugenol (4.18\%).
\end{abstract}

Keywords: (E)-cinnamyl acetate; $(E)$-cinnamaldehyde; biodegradation; biodeterioration; termiticide action; Ocotea quixos

\section{Introduction}

Ocotea quixos (Lam.) Kosterm. (Lauraceae) is a low-growing tree, reaching 5-30 m in height. The species has been reported in southern Colombia and Peru, although for many years it had been considered endemic to the rainforests of Ecuador [1]. The plant produces biannual calyxes with large, woody flowers, known as Ishpink or Ishpingo, which are customarily used as a spice by Amazonian inhabitants, as a substitute for cinnamon to flavour sweets and cakes. It can also be used as an aperitif, digestive, anti-diarrheal, antiseptic and anaesthetic [2-4]. Its leaves are used as an ingredient for infusions and drinks or to flavour food [2,3].

Ocotea quixos leaves are rich in essential oils (EOs), which people consider to be of high commercial value for use in industry and as natural food preservatives [5-8], cosmetic preservatives [9-11] or in general pharmaceutical applications [12-14]. The quantity of leaves that can be harvested is between 135 and $180 \mathrm{~kg} /$ tree/year in wild plants of 20-30 m height and between 45 and $100 \mathrm{~kg}$ in cultivated plants of 6-10 m [15]. 
The chemical profile of O. quixos leaves identified in Ecuador's Amazon region has been reported by certain authors. Pino et al. (2018) identified more than one hundred volatile compounds in EOs, of which 1,8-cineole (21.4\%) and p-cymene (12.6\%) stand out. Radice et al. (2019) also identified these constituents to be the most abundant in the oil, with concentration of $39.15 \%$ and $6.12 \%$ respectively. Other compounds present and likewise reported by the previous authors are limonene (1.84-9.2\%), $\alpha$-terpineol $(6.8-7.65 \%)$ and terpinen-4-ol (4.22-5.0\%). Other researchers for the same region indicated the highest proportions to be (E)- $\beta$-caryophyllene (15.1\%), cinnamyl acetate $(11.4 \%)$, sabinene $(7.6 \%)$, geranial (5.6\%) and trans-cinnamaldehyde (5.1\%) [4], or (E)- $\beta$-caryophyllene $(19.0 \%)$, humulene (14.3\%) and eremophilene (11.4\%) [16]. On the other hand, Scalvenzi et al. (2016) found trans-cinnamaldehyde $(16.6 \%),(E)$-methyl isoeugenol $(11.9 \%),(E)$ - $\beta$-caryophyllene $(10.6 \%)$ and $\alpha$-pinene $(9.4 \%)$ to be the majority compounds. The differences in the essential oil profile of $O$. quixos can be assigned to certain factors, such as the plant's age, climatic conditions, plant metabolism and distillation conditions or the part of the plant under analysis [17].

There are some studies regarding the biological properties of EO from O. quixos, including the following studies on the following activities: antiplatelet [18], antithrombotic [18,19], antifungal [20], antimicrobial [21,22], antioxidant [21,23], anti-inflammatory [24] and antiviral [25]. Nevertheless, this continues to be a novel field for scientific research, since reports are scarce. This field will allow for the development of natural products with biological activities and one interesting biological property, which has not been reported to date, is the anti-termite and repellent activity of $O$. quixos leaves, which would increase ecological alternatives for pest control as opposed to conventional (synthetic) products that have caused negative effects on the natural world and people's health [26].

Out of all the factors that lead to deterioration, termites are one of the most challenging pests threatening agriculture and cities. They cause substantial decreases of crop yield and damage wood structures at construction sites [27-29]. Since termites have become a great threat to the human economy, the use of essential oils, as an economic and ecological alternative, has been a widely used strategy for their biological control. Many plant oils have shown their termiticidal effect or have a repellent effect, for instance, Melaleuca species [30], Allium sativum, Eugenia caryophyllata [31], Caesalpinia coriaria [32], Vernicia fordii [33], Artemisia absinthium [34], Lavandula latifolia, Origanum vulgare, Syzygium aromaticum [35], Citrus aurantium, Cymbopogon citratus [36], Citrus grandis, Citrus paradisi [37], Schinus terebinthifolius, Pittosporum undulatum, Lippia sidoides, Mentha arvensis, Lippia gracilis, Croton cajucara [38], Eucalyptus citriodora [39] and Vetiveria zizanioides [40]. The active compounds of essential oils are very volatile and of short persistence in the environment due to their low molecular weight [41]. Therefore, these oil-based compounds appear environmentally safe and as a viable alternative to dangerous insecticides used in pest control [42].

The aim of this paper was therefore to predict the termiticidal and repellent activities of essential oil from $O$. quixos leaves against $N$. corniger using a one-factor response surface methodology design.

One dependable statistical technique of experiment design that is capable of predicting the relationship between response and independent variables is a response surface methodology (RSM) [43]. RSM statistically determines a regression model using a few pieces of adequate experimental data. The design type selection is dependent upon the number of variables in the study. In this study, RSM was applied in order to determine an approximate function linking essential oil concentrations with termite mortality and percentage of repellence. It is possible to employ a one-factor RSM design in order to discover the most suitable design points when there is only one continuous numerical factor within the investigation [44-46]. 


\section{Materials and Methods}

\subsection{Plant Material}

Healthy O. quixos leaves were gathered in the morning hours of January 2020 from ten remote individuals far apart located in the central campus of Universidad Estatal Amazónica, Puyo, Pastaza, Ecuador (1 ${ }^{\circ} 28^{\prime} 00.1^{\prime \prime}$ S $\left.77^{\circ} 59^{\prime} 49.0^{\prime \prime} \mathrm{W}\right)$. The scientific research authorization number of this study is 14-20-IC-FAU/FLO-DPAN/MA.

\subsection{Essential Oil Obtention}

EO from O. quixos leaves was obtained from steam distillation in an essential oil distiller (FIGMAY, Buenos Aires, Argentina). A $500 \mathrm{~g}$ sample of fresh leaves was put in the apparatus. The extraction with a continuous flow of water vapour was stopped after one hour when it was observed that successive readings of the volume of oil remained constant [34]. Five runs were made to obtain the EO in a single fraction. The oil was separated and placed on anhydrous sodium sulphate. A yield of $0.24 \%$ was obtained.

\subsection{Essential Oil Analysis}

\subsubsection{Equipment and Sample Preparation}

The analysis of $O$. quixos essential oil was performed by gas chromatography coupled with mass spectrometry (GC-MS) (Agilent Technologies 6890N, Santa Clara, CA, USA) and flame ionisation detection (GC-FID) (Agilent Technologies 7863, Little Falls, DE, USA). The GC-MS technique was utilised in the qualitative analysis, while GC-FID was applied in the quantitative analysis. Both processes were carried out with an Agilent Technologies 6890N gas chromatograph (Santa Clara, CA, USA) outfitted with a DB-5ms (5\% phenylpolydimethylsiloxane) capillary column that was $30 \mathrm{~m}$ long and had a $0.25 \mathrm{~mm}$ internal diameter and $0.25 \mu \mathrm{m}$ fixed-phase thickness (J\&W Scientific, Folsom, CA, USA). The injector was programmed in "Split" mode, with a 40:1 split ratio. The temperature was $250{ }^{\circ} \mathrm{C}$, injecting a volume of $1 \mu \mathrm{L}$. The thermal program used was as follows: $50{ }^{\circ} \mathrm{C}$ for $5 \mathrm{~min}$, thermal gradient of $3{ }^{\circ} \mathrm{C} / \mathrm{min}$ up to $155^{\circ} \mathrm{C}$, then $15^{\circ} \mathrm{C} / \mathrm{min}$ up to $250{ }^{\circ} \mathrm{C}$, which was maintained for $2 \mathrm{~min}$. The carrier gas was helium, in constant flow of $1 \mathrm{~mL} / \mathrm{min}$. The detector used in the GC-MS was an Agilent Technologies MSD 5963 mass spectrometer programmed in "SCAN" mode with a mass detection range of 35-350 $\mathrm{m} / \mathrm{z}$. The ion source was electronic ionization (EI), operating at $70 \mathrm{eV}$. In the GC-FID analysis, the detector was fed with air $\left(300 \mathrm{~mL} \mathrm{~min}^{-1}\right)$ and hydrogen $(30 \mathrm{~mL} / \mathrm{min})$, maintaining the temperature at $250{ }^{\circ} \mathrm{C}$.

The samples, both for qualitative and quantitative analyses, were prepared in duplicate; $10 \mu \mathrm{L}$ of essential oil was weighed and diluting with $1 \mathrm{~mL}$ of a $0.7 \mathrm{mg} / \mathrm{mL} n$-nonane solution (process standard, 99\% purity, BDH, Dubai, UAE) in cyclohexane (>98\% purity, Sigma-Aldrich, St. Louis, MO, USA).

\subsubsection{Qualitative Analysis}

The qualitative analysis was conducted by working out the linear retention rate of each component, following Van den Dool and Kratz [47], and comparing this parameter and the corresponding mass spectrum with the data reported in the reference literature [48]. The retention rates were calculated by mixing of alkanes, from $n$-nonane to $n$-pentacosane (99\% purity, Sigma-Aldrich, St. Louis, MO, USA). Assignments were accepted by mass spectrum matching within a range of retention rates of $+/-10$ units.

\subsubsection{Quantitative Analysis}

The quantitative analysis was realized by calculating the relative response factor (RRF) of each component in line with its combustion enthalpy $[49,50]$ with respect to isopropyl caproate as a standard of quantification. Each constituent was quantified with a calibration curve, using dilutions of $0.6,1.8,4.3,8.3,16.8$ and $34.3 \mathrm{mg}$ of isopropyl caproate in $10 \mathrm{~mL}$ of cyclohexane. Each dilution also had $7.0 \mathrm{mg}$ of $n$-nonane added as a process standard. The standard curve produced a correlation coefficient of 0.995 . In the author's laboratory, 
isopropyl caproate was obtained by synthesis (purity 97\% GC). Quantitative results were obtained as average values of the duplicate samples.

\subsection{Termite Collection and Identification}

Nasutitermes corniger were collected in areas surrounding the Universidad Estatal Amazónica, Puyo, Pastaza, Ecuador $\left(1^{\circ} 27^{\prime} 57.4^{\prime \prime}\right.$ S $77^{\circ} 59^{\prime} 56.7^{\prime \prime}$ W). Some affected portions of wood were removed from a tree trunk with a hand saw and transported with their own termite mounds to the laboratory in a plastic container. Additionally, wet filter papers were placed on the termites to maintain moisture. Termites selected were maintained at $24{ }^{\circ} \mathrm{C}$ and $92 \%$ relative humidity, and they were monitored for the next $24 \mathrm{~h}$ before being used for testing. For each analysis thirty healthy and active adult termites ( 25 workers along with 5 soldiers) were collected in a Petri dish with wet filter paper.

The entomological identification of insects was carried out in two different laboratories belonging to the Phyto and Zoosanitary Regulation and Control Agency (AGROCALIDAD) of Ecuador. The first one is located between Gonzalo Zaldumbide and Ernesto Noboa streets, in the Huachi Chico Sector, Ambato (voucher code PGT/LRD-E-18/09-F001). The other is located between the Via Interoceánica $\mathrm{km} 14 \frac{1}{2}$ and Eloy Alfaro Street, Tumbaco, Quito (voucher code PGT/E/09-F001).

\subsection{Mortality and Repellency Tests Experimental Design}

2.5.1. One-Factor Response Surface Methodology

Before applying the experimental design model, preliminary tests were carried out to determine the termite mortality concentration range of the O. quixos $\mathrm{EO}(0.05-1 \% v / v)$ in ethanol 95\% (HPLC grade, Sigma-Aldrich, St. Louis, MO, USA).

The results of these tests showed that concentrations greater than $0.3 \%$ generated a mortality of termites greater than $100 \%$ and this value was inserted together with the minimum concentration of $0.05 \%$ in Design Expert software, version 12 (serial number 9847 9696-7992-6750, Minneapolis, MN, USA). The program suggested a pool of concentrations to be tested for the one-factor RSM design (Table 1) between concentrations of EO from 0.05 to $0.30 \%$.

Table 1. One-factor response surface methodology design based upon independent variables (EO concentration) and experimental and predicted results of the antitermitic and repellent activities.

\begin{tabular}{|c|c|c|c|c|c|c|}
\hline \multirow{2}{*}{ Experiment } & \multirow{2}{*}{$\begin{array}{c}\text { Concentration of } \\
\text { Essential Oil }(\% ; v / v)\end{array}$} & \multicolumn{2}{|c|}{ Termite Mortality (\%) } & \multirow{2}{*}{$\begin{array}{c}\text { Concentration of } \\
\text { Essential Oil }(\% ; v / v)\end{array}$} & \multicolumn{2}{|c|}{ Termite Repellency (\%) } \\
\hline & & Experimental * & Predicted & & Experimental * & Predicted \\
\hline 1 & 0.24 & $100 \pm 0.0$ & 100 & 0.06 & $58.9 \pm 1.9$ & 62.0 \\
\hline 2 & 0.05 & $20.0 \pm 3.3$ & 20.5 & 0.12 & $100 \pm 0.0$ & 99.2 \\
\hline 3 & 0.30 & $100 \pm 0.0$ & 100 & 0.06 & $60.0 \pm 3.3$ & 62.0 \\
\hline 4 & 0.18 & $100 \pm 0.0$ & 99.67 & 0.01 & $50.0 \pm 3.3$ & 49.5 \\
\hline 5 & 0.30 & $100 \pm 0.0$ & 100 & 0.03 & $54.4 \pm 3.8$ & 52.7 \\
\hline 6 & 0.11 & $96.7 \pm 1.9$ & 96.6 & 0.11 & $97.8 \pm 1.9$ & 99.2 \\
\hline 7 & 0.05 & $22.2 \pm 1.9$ & 20.5 & 0.09 & $80.0 \pm 3.3$ & 77.5 \\
\hline 8 & 0.18 & $100 \pm 0.0$ & 99.7 & 0.01 & $48.9 \pm 1.9$ & 49.5 \\
\hline 9 & 0.18 & $98.9 \pm 1.9$ & 99.7 & 0.06 & $62.2 \pm 1.9$ & 62.0 \\
\hline
\end{tabular}

* These values were conveyed as means of three determinations \pm SD.

Based on the theoretical value of the minimum oil concentration predicted by the response surface model, for which mortality corresponded to $100 \%$, a new design was made to evaluate repellent activity. The maximum value selected was $0.12 \%$ and the minimum was $0.01 \%$.

Both designs - the mortality test and the repellent activity-were executed with three replicates and the mean values were used for the analyses. The variance analysis was harnessed to estimate the influence of $O$. quixos $\mathrm{EO}$ concentration as an independent variable $(p<0.05)$. The model's fitness was determined using the coefficient of determination $\left(\mathrm{R}^{2}\right)$ and significance $(p)$. The results for the predicted and experimental data are shown in Table 1. 


\subsubsection{Model Validation}

The validity of the experimental design was verified using additional experiments with three replicates using the predicted concentration.

\subsection{Mortality Test}

The in vitro termiticide activity test [51] was performed at different concentrations of O. quixos EO in 95\% ethanol (see experimental design in Section 2.5.1). First, $1 \mathrm{~mL}$ of each $\mathrm{EO}$ concentration in ethanol was placed on a $9 \mathrm{~cm}$ diameter filter paper, according to the experimental design, and the solvent was left to fully evaporate at room temperature. The filter paper treated with $1 \mathrm{~mL}$ of ethanol was taken as a blank. Then, $1 \mathrm{~mL}$ of distilled water was added to each treatment. Thirty termites were placed ( 5 soldiers and 25 workers) on each piece of filter paper saturated with the evaluated concentrations of essential oil in a Petri dish $(9 \mathrm{~cm}$ diameter $\times 1.5 \mathrm{~cm}$ high). The percentage of mortality was evaluated at $24 \mathrm{~h}$ using the following equation (Equation (1)):

$$
\% \text { of dead termites }=\left(\frac{\text { Mean of dead termites }}{\text { No. of termites taken initially }}\right) \times 100
$$

\subsection{Repellency Test}

The repellent activity was established in line with Bakaruddin et al. [52]. The filter papers were cut according to the size of the Petri dish and divided into half. To one of the halves was added $0.5 \mathrm{~mL}$ of each EO concentration (see experimental design in Section 2.5.1) and the other half was used as a blank with $95 \%$ ethanol and distilled water. Thirty worker termites were released into the centre. The quantity of termites in the treated and untreated zones was counted after a time interval of $60 \mathrm{~min}$.

\section{Results}

\subsection{Termiticidal and Repellent Activity of EO}

Based on the one-factor RSM design, nine runs were conducted to find the minimum optimal concentration of O. quixos EO that would produce $100 \%$ termite mortality and the greatest repellent action. Table 1 shows which experimental and predicted values were utilized to develop the model. Mortality values between $20.00 \% \pm 3.3$ and $100.00 \% \pm 0.0$ were observed for the entire concentration range evaluated.

The fourth order polynomial model (Table 2) consisted of the best fit. The R2 value corresponded to 0.9998 for the termiticide test, indicating that $99.98 \%$ of the total variation in termite death was determined by the EO concentration.

Table 2. Summary of the polynomial models analysed by Design Expert software in the optimization of the O. quixos $\mathrm{EO}$ concentration.

\begin{tabular}{lccccc}
\hline \multicolumn{1}{c}{ Mortality } & $\begin{array}{c}\text { Sequential } \\
\boldsymbol{p} \text {-Value }\end{array}$ & $\begin{array}{c}\text { Lack of Fit } \\
\boldsymbol{p} \text {-Value }\end{array}$ & $\begin{array}{c}\text { Adjusted } \\
\text { R-Squared }\end{array}$ & $\begin{array}{c}\text { Predicted } \\
\text { R-Squared }\end{array}$ & \\
\hline Linear & 0.0153 & $<0.0001$ & 0.5342 & 0.2688 & \\
Quadratic & 0.0018 & $<0.0001$ & 0.9049 & 0.8743 & \\
Cubic & 0.0031 & $<0.0001$ & 0.9829 & 0.9343 & Suggested \\
Quartic & $<0.0001$ & & 0.9998 & & Aliased \\
Fifth & & & & & \\
\hline Repellency & Sequential & Lack of Fit & Adjusted & Predicted & \\
& $p$-value & $p$-value & R-Squared & R-Squared & \\
Linear & 0.0001 & 0.0030 & 0.8820 & 0.8244 & Suggested \\
Quadratic & 0.0004 & 0.1540 & 0.9858 & 0.9796 & \\
Cubic & 0.9266 & 0.0679 & 0.9830 & 0.9499 & Aliased \\
Quartic & 0.0679 & & 0.9917 & & \\
Fifth & & & & &
\end{tabular}


The predicted values of mortality relative to the model and those obtained empirically were compared and can be visualized in Figure 1a. The distribution of points confirmed the model's capacity to cover the entire range of experiments studied, which suggested that the model could be applied effectively [53,54]. The values of $R^{2}$ and adjusted $R^{2}$ of both regression lines were close to 1 , indicating a good agreement between the model's experimental and predicted values at the design points. In Figure 1c, it can be seen that the experimental data met the normal distribution assumption. Moreover, according to the results of Table 3, it was confirmed that concentration was a significant factor $(p<0.05)$.

(a)

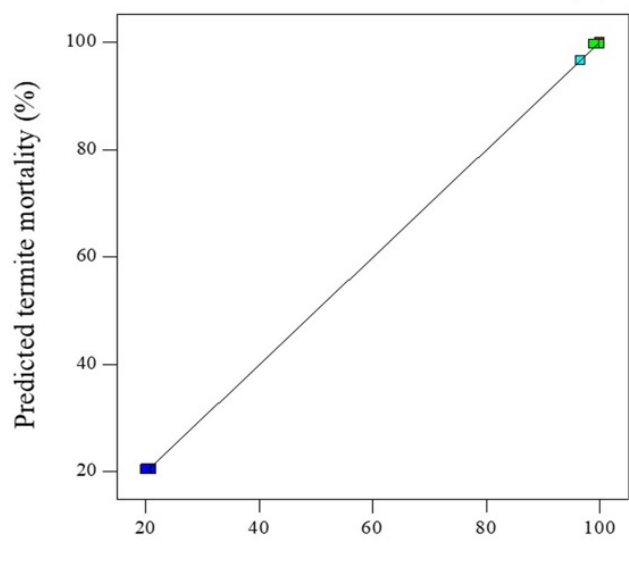

Experimental termite mortality (\%)

(c)

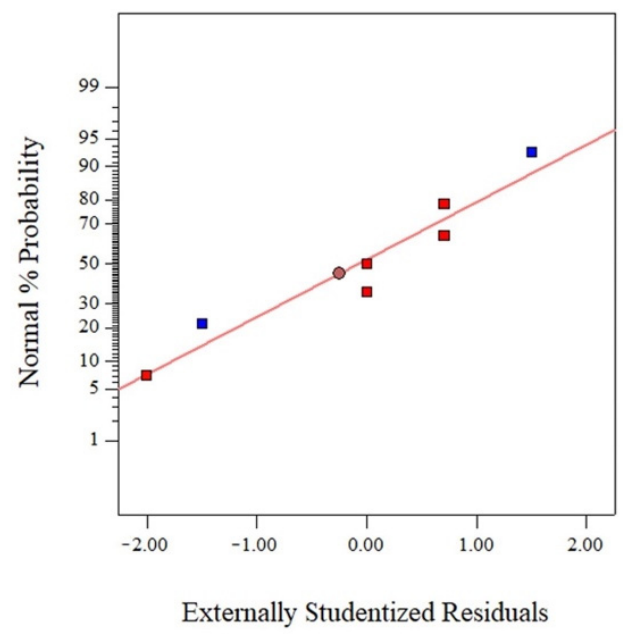

(b)

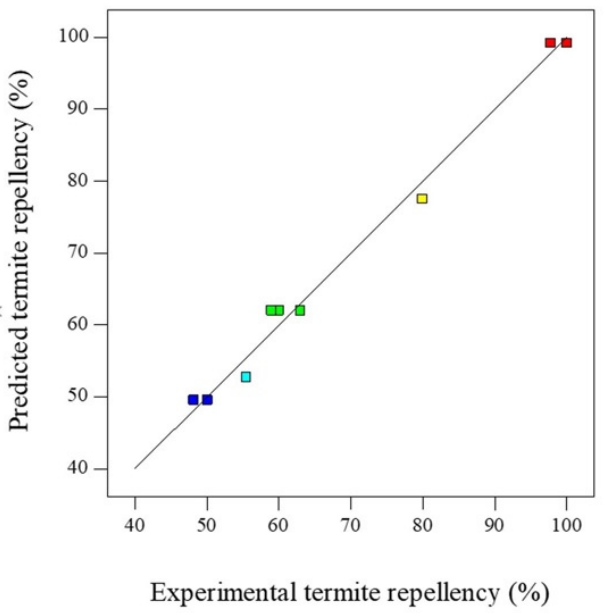

(d)

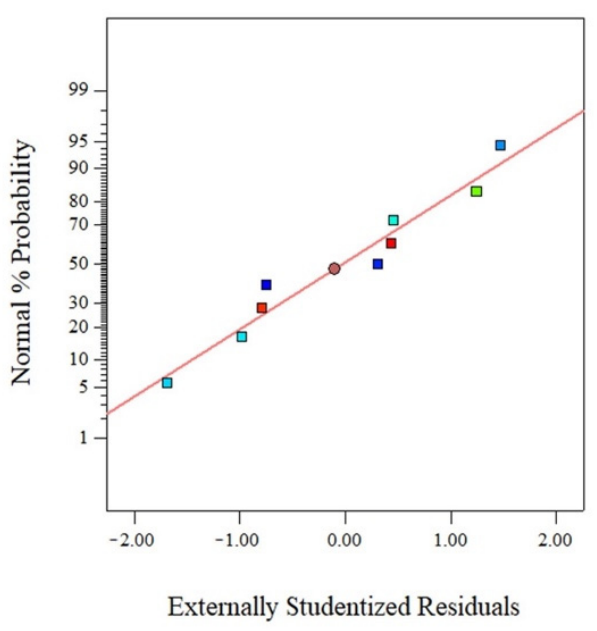

Figure 1. Experimental versus predicted values for one-factor design: (a) termite mortality $\left(R^{2}=0.9999\right.$; adjusted $\left.R^{2}=0.9998\right)$, $(b)$ repellency $\left(R^{2}=0.9894\right.$; adjusted $\left.R^{2}=0.9858\right)$. (c, d) Normal distribution of experimental data.

For the repellent action, the polynomial model was of the second order, with an $\mathrm{R}^{2}$ value of 0.9858 (Figure 1b, Table 2), which also indicated the dose-dependent effect and that $98.58 \%$ of the total variance of the repellent action was influenced by the concentration. The experimental data also complied with the normal distribution (Figure 1d). 
Table 3. ANOVA test for response surface quartic model (termite mortality) and for response surface quadratic model (repellency).

\begin{tabular}{lcccccc}
\hline \multicolumn{1}{c}{ Mortality } & Sum of Squares & df & Mean Square & F-Value & $p$-Value Prob $>$ F \\
\hline Quartic model & 9685.78 & 4 & 2421.44 & 8302.09 & $<0.0001$ & Significant \\
A-concentration & 21.20 & 1 & 21.20 & 72.70 & 0.0010 & 0.0848 \\
$\mathrm{~A}^{2}$ & 1.52 & 1 & 1.52 & 5.20 & $<0.0001$ \\
$\mathrm{~A}^{3}$ & 587.25 & 1 & 587.25 & 2013.44 & $<0.0001$ \\
$\mathrm{~A}^{4}$ & 102.45 & 1 & 102.45 & 351.27 & & \\
Pure error & 1.17 & 4 & 0.29 & & & Significant \\
Total corr. & 9686.94 & 8 & & & & \\
\hline \multicolumn{1}{c}{ Repellency } & Sum of Squares & df & Mean Square & F-Value & $p$-Value Prob $>$ F \\
Quadratic model & 3061.19 & 2 & 1530.60 & 279.14 & $<0.0001$ & $<0.0001$ \\
A-concentration & 2774.63 & 1 & 2774.63 & 506.02 & 0.0004 & \\
A $^{2}$ & 286.57 & 1 & 286.57 & 52.26 & & \\
Pure error & 12.91 & 4 & 3.23 & & & \\
Total corr. & 3094.09 & 8 & & & \\
\hline
\end{tabular}

The software generated fourth- and second-order polynomial equations for termiticidal and repellent activity respectively. These models made it possible to find the relationship between the $O$. quixos $\mathrm{EO}$ concentration (EOC, \% v/v) and the predicted response: percentage of dead termites (Equation (2)) and percentage of repellency (Equation (3)).

Termite mortality $=-183.55+6053.87 \times \mathrm{EOC}-46,722.94 \times \mathrm{EOC}^{2}+1.55 \mathrm{E} 005 \times \mathrm{EOC}^{3}-1.85 \mathrm{E} 005 \times \mathrm{EOC}^{4}$

$$
\text { Percentage of repellency }=49.92-79.81 \times \mathrm{EOC}+4086.83 \times \mathrm{EOC}^{2}
$$

The statistical significance of the regression equations with regard to the polynomial model of the surface response was checked using the F and ANOVA tests (Table 3), and the representations of the regression equations simulated by the software are shown in Figure 2a,b.

According to the models, the minimum optimal concentration at which $100 \%$ of termites would die was $0.12 \%$ and for repellency - with more than $99 \%$ of termites repelledthe minimum concentration was also $0.12 \%$. Figure $2 \mathrm{c}$, d show the high correlation between the concentration of $\mathrm{EO}$ and the responses found. These minimum concentrations were validated experimentally and at $0.12 \%$ both termite mortality and repellency were $100 \%$.

\subsection{Essential Oil Analysis}

A GC-MS analysis of the EO from O. quixos leaves made it possible to establish the presence of 42 compounds and to identify 39 different substances (Figure 3, Table 4).

The essential oil was mostly composed of esters $(37.62 \%)$, aromatic aldehydes $(28.07 \%)$ and sesquiterpenes $(13.95 \%)$. The main compounds were $(E)$-cinnamyl acetate $(36.44 \%),(E)$ cinnamaldehyde (27.03\%), (E)- $\beta$-caryophyllene $(5.21 \%)$ and $(E)$-methyl isoeugenol $(4.18 \%)$. Although the data found by [19] regarding EO from O. quixos leaves revealed a different chromatographic profile, the main compounds were similar. 
(a)

(b)
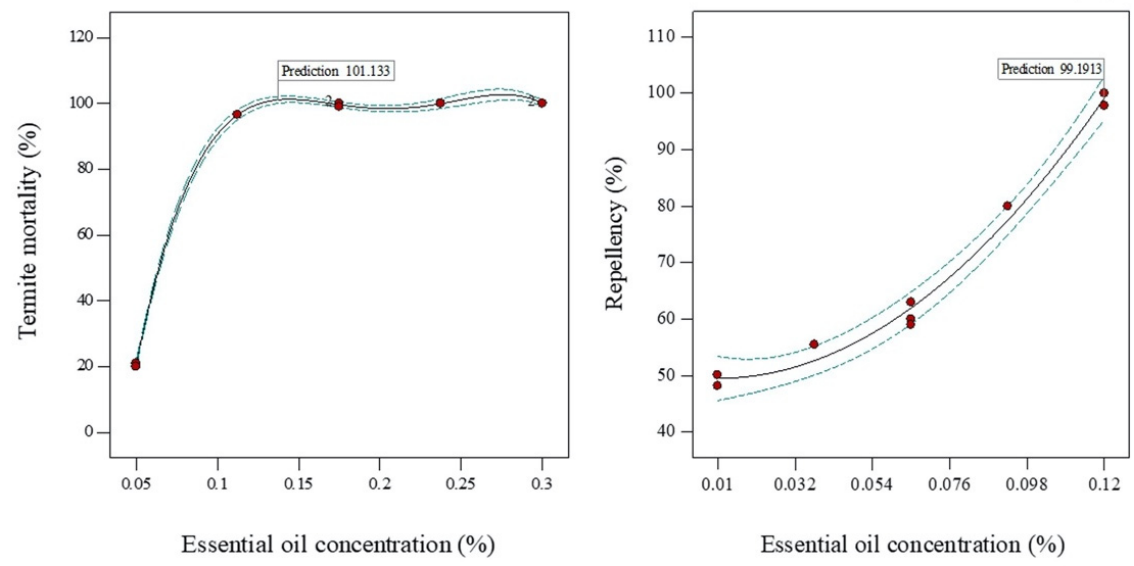

(c)

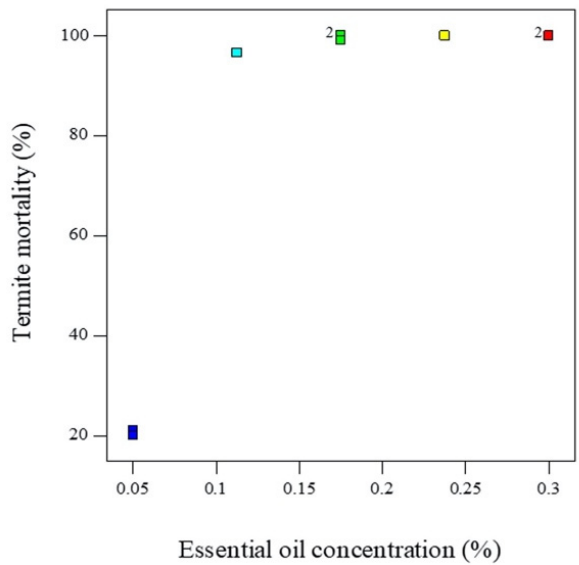

(d)

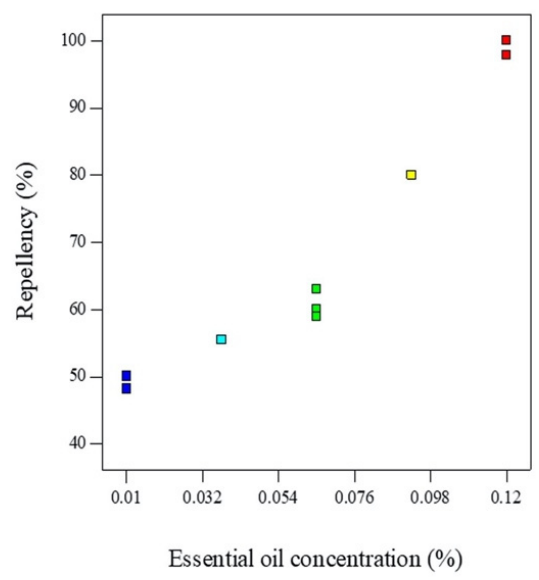

Figure 2. Model graph for one-factor design: (a) termite mortality, (b) repellency. Correlation between concentration and response variables: $(\mathbf{c})$ termite mortality $(0.770),(\mathbf{d})$, repellency $(0.947)$.



Figure 3. GC-MS chromatogram of $O$. quixos essential oil in DB-5ms column. 
Table 4. O. quixos leaf essential oil composition.

\begin{tabular}{|c|c|c|c|c|c|}
\hline No. & RT (min) & $\mathbf{L I R}_{\text {cal }}$ & LIR $_{\text {ref }} A$ & Compound & $\%$ \\
\hline 1 & 8.93 & 930 & 923 & $\alpha$-pinene & 3.09 \\
\hline 2 & 9.66 & 945 & 946 & camphene & 0.13 \\
\hline 3 & 10.28 & 958 & 952 & benzaldehyde & 0.79 \\
\hline 4 & 10.79 & 969 & 975 & sabinene & 0.70 \\
\hline 5 & 10.98 & 973 & 979 & $\beta$-pinene & 1.91 \\
\hline 6 & 11.68 & 988 & 988 & $\beta$-myrcene & 0.21 \\
\hline 7 & 13.56 & 1026 & 1024 & limonene & 0.55 \\
\hline 8 & 13.70 & 1029 & 1026 & 1,8-cineole & 0.68 \\
\hline 9 & 15.04 & 1056 & 1054 & $\gamma$-terpinene & 0.08 \\
\hline 10 & 17.25 & 1100 & 1095 & linalool & 0.13 \\
\hline 11 & 20.19 & 1160 & $1160^{\mathrm{B}}$ & hydrocinnamaldehyde & 0.12 \\
\hline 12 & 21.07 & 1178 & 1174 & 4-terpineol & 0.16 \\
\hline 13 & 21.82 & 1193 & 1186 & $\alpha$-terpineol & 0.20 \\
\hline 14 & 22.89 & 1216 & 1217 & (Z)-cinnamaldehyde & 0.13 \\
\hline 15 & 25.53 & 1272 & 1267 & (E)-cinnamaldehyde & 27.03 \\
\hline 16 & 29.94 & 1371 & 1374 & $\alpha$-copaene & 1.46 \\
\hline 17 & 30.39 & 1381 & 1376 & (E)-methyl cinnamate & \\
\hline 18 & 30.49 & 1384 & 1376 & $\beta$-cubebene & $2.45 *$ \\
\hline 19 & 30.57 & 1385 & 1389 & $\beta$-elemene & \\
\hline 20 & 31.78 & 1414 & 1417 & (E)- $\beta$-caryophyllene & 5.21 \\
\hline 21 & 33.12 & 1446 & 1443 & (E)-cinnamyl acetate & 36.44 \\
\hline 22 & 33.27 & 1450 & 1452 & $\alpha$-humulene & 0.29 \\
\hline 23 & 33.90 & 1465 & 1471 & 4,5-di-epi-aristolochene & 0.34 \\
\hline 24 & 34.31 & 1475 & 1480 & germacrene D & 0.48 \\
\hline 25 & 34.65 & 1483 & 1489 & $\beta$-selinene & 0.61 \\
\hline 26 & 34.93 & 1490 & 1500 & bicyclogermacrene & 1.81 \\
\hline 27 & 35.11 & 1494 & 1491 & $(E)$-methyl isoeugenol & 4.18 \\
\hline 28 & 35.54 & 1505 & 1505 & $\beta$-bisabolene & 0.46 \\
\hline 29 & 35.78 & 1511 & 1514 & cubebol & 0.23 \\
\hline 30 & 35.89 & 1514 & 1522 & $\delta$-cadinene & 0.66 \\
\hline 31 & 36.27 & 1523 & 1529 & $(E)-\gamma$-bisabolene & 0.77 \\
\hline 32 & 36.76 & 1536 & 1544 & $\alpha$-calacorene & 0.23 \\
\hline 33 & 38.15 & 1571 & 1577 & spathulenol & 0.24 \\
\hline 34 & 38.32 & 1576 & 1582 & caryophyllene oxide & 3.70 \\
\hline 35 & 39.39 & 1604 & 1608 & humulene epoxide II & \\
\hline 36 & 40.07 & 1629 & 1630 & $\beta$-muurola-4,10(14)-dien-1-ol & $0.77^{* *}$ \\
\hline 37 & 40.30 & 1637 & & undetermined (MW 220) & \\
\hline 38 & 40.42 & 1641 & 1639 & $\begin{array}{l}\beta \text {-caryophylla-4(12),8(13)-dien- } \\
5 \text {-ol }\end{array}$ & $0.23+7+7$ \\
\hline 39 & 41.02 & 1663 & & undetermined (MW 222) & 0.50 \\
\hline 40 & 41.22 & 1670 & & undetermined (MW 220) & 0.35 \\
\hline 41 & 41.37 & 1675 & & undetermined (MW 220) & 0.36 \\
\hline 42 & 43.09 & 1769 & 1759 & benzyl benzoate & 0.36 \\
\hline \multicolumn{5}{|c|}{ Monoterpenes } & 6.67 \\
\hline \multicolumn{5}{|c|}{ Oxygenated monoterpenes } & 1.16 \\
\hline \multicolumn{5}{|c|}{ Aromatic aldehydes } & 28.07 \\
\hline \multicolumn{5}{|c|}{ Sesquiterpenes } & 13.95 \\
\hline \multicolumn{5}{|c|}{ Oxygenated sesquiterpenes } & 6.38 \\
\hline \multicolumn{5}{|c|}{ Esters } & 37.62 \\
\hline \multicolumn{5}{|l|}{ Others } & 4.18 \\
\hline \multicolumn{5}{|l|}{ Total } & 98.02 \\
\hline
\end{tabular}

RT: retention time; $\mathrm{LRI}_{\mathrm{cal}}$ : calculated linear retention index; $\mathrm{LRI}_{\text {ref }}$ : reference linear retention index; ${ }^{\mathrm{A}}[48] ;{ }^{\mathrm{B}}[55]$ MW: molecular weight. * The composition corresponds to the sum of $(E)$-methyl cinnamate, $\beta$-cubebene and $\beta$-elemene. ${ }^{* *}$ The composition corresponds to the sum of humulene epoxide II and $\beta$-muurola-4,10(14)-dien-1-ol *** The composition corresponds to the sum of the indeterminate compounds and $\beta$-caryophylla-4(12),8(13)-dien5-ol.

\section{Discussion}

The results obtained demonstrate the effectiveness of EO from O. quixos leaves at low concentrations. It is known that many plant-derived essential oils and their constituents exhibit anti-termite activity against various species of termites. Gupta [54] evaluated the effects of six species (Mentha arvensis, Carum capticum, Cymbopogon citrates, Eugenia caryophyllata, Cedrus deodara and Eucalyptus globulus) against the termite Odontotermes obesus and found that $M$. arvensis oil yielded the best results (100\% mortality in $30 \mathrm{~min}$ with a $10 \%$ oil concentration and in $10 \mathrm{~h}$ with $0.12 \%$ ). In second and third places were C. capticum and C. citrates. For all oils evaluated at concentrations above $10 \%$, termite mortality at $30 \mathrm{~min}$ was $100 \%$. Variable mortality rates were detected with oils at concentrations below $10 \%$. Nonetheless, EO concentrations as low as $0.12 \%$ were sufficient for the death of all termites at $18 \mathrm{~h}$. Chang and Cheng [56] reported that the anti-termite activity of Cinnamomum osmophloeum leaf essential oil at a dose of $0.5 \%$ exterminated all termites over a 14 day time period. Cheng et al. [57] stated that the leaf oil of Calocedrus macrolepis var. formosana 
with the same dose and time achieved $77 \%$ mortality. Several eucalyptus essential oils (E. camaldulensis, E. citriodora, E. tereticornis, E. pseudoglobulus and E. maidenii) have been evaluated for toxicity against Coptotermes gestroi. All oils tested instigated $100 \%$ mortality of C. gestroi at 10\%. At 5\%, only E. citriodora, E. ereticornis and E. maidenii oils produced mortality rates of $80 \%$ or more. Lastly, at $1.25 \%$, only E. citriodora oil resulted in mortality of $80 \%$ or more [58].

Other researchers have confirmed that certain essential oils, for instance, cedarwood oil (common name of EOs from many species of the family Cupressaceae) [59], Cinnamomum spp. [60], Vetiveria zizanioides, Cinnamomum cassia, Eugenia caryophyllata, Juniperus virginiana, Eucalyptus globulus, Eucalyptus citriodora, Cymbopogon citratus and Pelargonium graveolens [61], exercise termite-repelling activity.

In accordance with the oil's chemical composition, it is possible to attribute the antitermite activity to its main components: $(E)$-cinnamyl acetate and $(E)$-cinnamaldehyde. The high effectiveness of these compounds against Coptotermes formosanus has been independently evaluated by Chang and Cheng [56]. The toxicity of Cinnamomum osmophleum (cinnamon) EO with the presence of cinnamaldehyde at $76 \%$ has also been reported against Macrotermes gilvus [62]. Preparations with cinnamaldehyde and cinnamic acid have shown effective activity against the subterranean termites species of C. formosanus Shiraki [60]. Since the present study pertained to the biological activity of a specific botanical batch, it did not take into account the possible variance in the chemical composition of the EO. For this reason, we actually consider this study as a preliminary approach to the problem. However, all the data from literature show that the known EOs of O. quixos mainly present a similar chemical profile, always characterised by cinnamic acid derivatives as major components. Hence, we think that similar results could be expected in a wider investigation.

\section{Conclusions}

The surface response methodology made it possible to find a preliminary predictive model for the evaluation of the optimal O. quixos essential oil concentration at which 100\% termite mortality is achieved. This study demonstrated that O. quixos essential oil, at very low concentrations $(0.12 \%)$, presents termiticidal and repellent effect against $N$. corniger. The findings theoretically open the way to the use of this EO as a natural biopesticide against termites, viable also in the rural context where different plantations are cultivated. Future research should examine the formulation of biopreparations in the hope of finding useful and renewable substitutes for some currently used chemical biocides. The O. quixos essential oil studied is rich in esters and aromatic aldehydes, particularly (E)-cinnamyl acetate $(36.44 \%)$ and $(E)$-cinnamaldehyde (27.03\%). Finally, the O. quixos EO is suggested for further and wider research in order to deepen the termiticidal and repelling activity with consideration of the ecological chemical variance of this species.

Author Contributions: Conceptualization and investigation, all authors; writing-original draft, Y.A.-C. and M.M.; writing-review \& editing, Y.A.-C., D.U.-L., G.G., O.M. and Y.G.-Q. All authors have read and agreed to the published version of the manuscript.

Funding: This research received funding from Universidad Estatal Amazónica, Universidad Técnica Particular de Loja and PROAmazonia-UTPL Project.

Data Availability Statement: Raw data are available from the authors.

Acknowledgments: The authors thank the Universidad Estatal Amazónica (UEA) for the acquisition of Design Expert version 12 software (Serial Number 9847-9696-7992-6750) and for providing the resources for this research. We also thank the Universidad Técnica Particular de Loja (UTPL) for the technical assistance provided. The UTPL team acknowledge PROAmazonía funding (Ministerio del Ambiente y Agua, Ministerio de Agricultura y Ganadería, Programa de las Naciones Unidas para el Desarrollo (PNUD)). The authors wish to thank personnel from the Phyto and Zoosanitary Regulation and Control Agency (AGROCALIDAD) of Ecuador for the identification of termites. 
Conflicts of Interest: The authors declare no conflict of interest.

\section{References}

1. Jørgensen, P.M.; León-Yánez, S. Catalogue of the Vascular Plants of Ecuador; Missouri Botanical Garden: St. Louis, MO, USA, 1999; Volume 75.

2. Friedman, J.; Bolotin, D.; Rios, M.; Mendosa, P.; Cohen, Y.; Balick, M.J. A Novel Method for Identification and Domestication of indigenous Useful Plants in Amazonian Ecuador; Janick, J., Simon, J.E., Eds.; John Wiley and Sons Inc.: New York, NY, USA, 1993; pp. 167-174.

3. Naranjo, P.; Kijjoa, A.; Giesbrecht, A.M.; Gottlieb, O.R. Ocotea quixos, American cinnamon. J. Ethnopharmacol. 1981, 4, 233-236. [CrossRef]

4. Sacchetti, G.; Guerrini, A.; Noriega, P.; Bianchi, A.; Bruni, R. Essential oil of wild Ocotea quixos (Lam.) Kosterm. (Lauraceae) leaves from Amazonian Ecuador. Flavour Fragr. J. 2006, 21, 674-676. [CrossRef]

5. Gavahian, M.; Chu, Y.H.; Lorenzo, J.M.; Mousavi Khaneghah, A.; Barba, F.J. Essential oils as natural preservatives for bakery products: Understanding the mechanisms of action, recent findings, and applications. Crit. Rev. Food Sci. Nutr. 2020, 60, 310-321. [CrossRef] [PubMed]

6. Olmedo, R.H.; Grosso, N.R. Oxidative stability, affective and descriptive sensory properties of roasted peanut flavored with oregano, laurel, and rosemary essential oils as natural preservatives of food lipids. Eur. J. Lipid Sci. Technol. 2019, 121, 1800428. [CrossRef]

7. Prakash, B.; Kedia, A.; Mishra, P.K.; Dubey, N.K. Plant essential oils as food preservatives to control moulds, mycotoxin contamination and oxidative deterioration of agri-food commodities-Potentials and challenges. Food Control. 2015, 47, 381-391. [CrossRef]

8. Smith-Palmer, A.; Stewart, J.; Fyfe, L. The potential application of plant essential oils as natural food preservatives in soft cheese. Food Microbiol. 2001, 18, 463-470. [CrossRef]

9. Carvalho, I.T.; Estevinho, B.N.; Santos, L. Application of microencapsulated essential oils in cosmetic and personal healthcare products-A review. Int. J. Cosmet. Sci. 2016, 38, 109-119. [CrossRef] [PubMed]

10. Muyima, N.Y.O.; Zulu, G.; Bhengu, T.; Popplewell, D. The potential application of some novel essential oils as natural cosmetic preservatives in an aqueous cream formulation. Flavour Fragr. J. 2002, 17, 258-266. [CrossRef]

11. Herman, A. Antimicrobial ingredients as preservative booster and components of self-preserving cosmetic products. Curr. Microbiol. 2019, 76, 744-754. [CrossRef]

12. Deng, W.; Liu, K.; Cao, S.; Sun, J.; Zhong, B.; Chun, J. Chemical composition, antimicrobial, antioxidant, and antiproliferative properties of grapefruit essential oil prepared by molecular distillation. Molecules 2020, 25, 217. [CrossRef]

13. Yin, C.; Sun, F.; Rao, Q.; Zhang, Y. Chemical compositions and antimicrobial activities of the essential oil from Pterocarya stenoptera C. DC. Nat. Prod. Res. 2019, 34, 1-4. [CrossRef] [PubMed]

14. Camele, I.; Elshafie, H.S.; De Feo, V.; Caputo, L. Anti-quorum sensing and antimicrobial effect of Mediterranean plant essential Oils against phytopathogenic bacteria. Front. Microbiol. 2019, 10, 2619. [CrossRef] [PubMed]

15. Espinoza, G.J.T. El Aprovechamiento del Ishpink (Ocotea quixos). Manual de Buenas Prácticas de Recolección. Available online: http:/ / chankuap.org/wp-content/uploads/2014/03/Manual-de-buenas-practicas-de-la-Ishpink.pdf (accessed on 20 May 2020).

16. Noriega, P.; Dacarro, C. Aceite foliar de Ocotea quixos (Lam.) Kosterm.: Actividad antimicrobiana y antifúngica. Granja 2008, 7, 3-8. [CrossRef]

17. Figueiredo, A.C.; Barroso, J.G.; Pedro, L.G.; Scheffer, J.J.C. Factors affecting secondary metabolite production in plants: Volatile components and essential oils. Flavour Fragr. J. 2008, 23, 213-226. [CrossRef]

18. Tognolini, M.; Barocelli, E.; Ballabeni, V.; Bruni, R.; Bianchi, A.; Chiavarini, M.; Impicciatore, M. Comparative screening of plant essential oils: Phenylpropanoid moiety as basic core for antiplatelet activity. Life Sci. 2006, 78, 1419-1432. [CrossRef]

19. Ballabeni, V.; Tognolini, M.; Bertoni, S.; Bruni, R.; Guerrini, A.; Rueda, G.M.; Barocelli, E. Antiplatelet and antithrombotic activities of essential oil from wild Ocotea quixos (Lam.) Kosterm. (Lauraceae) calices from Amazonian Ecuador. Pharmacol. Res. 2007, 55, 23-30. [CrossRef] [PubMed]

20. Scalvenzi, L.; Yaguache-Camacho, B.; Cabrera-Martinez, P.; Guerrini, A. In vitro antifungal activity of essential oils of Ocotea quixos (Lam.) Kosterm. and Piper aduncum L. Bioagro 2016, 28, 39-46.

21. Pino, J.A.; Fon-Fay, F.M.; Falco, A.S.; Pérez, J.C.; Hernández, I.; Rodeiro, I.; Fernández, M.D. Chemical composition and biological activities of essential oil from Ocotea quixos (Lam.) Kosterm. leaves grown wild in Ecuador. Am. J. Essent. Oils Nat. Prod. 2018, 6, 31-34.

22. Calderón, F.G.O.; García, P.L.G.; Ortiz, Y.L.S. Chemical composition and antioxidant and antibacterial activity of Ocotea quixos. Rev. Cuba. Plant. Med. 2018, 23, 1-15.

23. Bruni, R.; Medici, A.; Andreotti, E.; Fantin, C.; Muzzoli, M.; Dehesa, M.; Romagnoli, C.; Sacchetti, G. Chemical composition and biological activities of Ishpingo essential oil, a traditional Ecuadorian spice from Ocotea quixos (Lam.) Kosterm. (Lauraceae) flower calices. Food Chem. 2004, 85, 415-421. [CrossRef]

24. Ballabeni, V.; Tognolini, M.; Giorgio, C.; Bertoni, S.; Bruni, R.; Barocelli, E. Ocotea quixos Lam. essential oil: In vitro and in vivo investigation on its anti-inflammatory properties. Fitoterapia 2010, 81, 289-295. [CrossRef] 
25. Radice, M.; Pietrantoni, A.; Guerrini, A.; Tacchini, M.; Sacchetti, G.; Chiurato, M.; Venturi, G.; Fortuna, C. Inhibitory effect of Ocotea quixos (Lam.) Kosterm. and Piper aduncum L. essential oils from Ecuador on west Nile virus infection. Plant Biosyst. Int. J. Deal. Asp. Plant Biol. 2019, 153, 344-351. [CrossRef]

26. Pandey, A.; Chattopadhyay, P.; Banerjee, S.; Pakshirajan, K.; Singh, L. Antitermitic activity of plant essential oils and their major constituents against termite Odontotermes assamensis Holmgren (Isoptera: Termitidae) of north east India. Int. Biodeterior. Biodegrad. 2012, 75, 63-67. [CrossRef]

27. Santos, A.A.; de Oliveira, B.M.S.; Melo, C.R.; Lima, A.P.S.; Santana, E.D.R.; Blank, A.F.; Picanço, M.C.; Araújo, A.P.A.; Cristaldo, P.F.; Bacci, L. Sub-lethal effects of essential oil of Lippia sidoides on drywood termite Cryptotermes brevis (Blattodea: Termitoidea). Ecotoxicol. Environ. Saf. 2017, 145, 436-441. [CrossRef]

28. Siramon, P.; Ohtani, Y.; Ichiura, H. Biological performance of Eucalyptus camaldulensis leaf oils from Thailand against the subterranean termite Coptotermes formosanus Shiraki. J. Wood Sci. 2009, 55, 41-46. [CrossRef]

29. Verma, M.; Sharma, S.; Prasad, R. Biological alternatives for termite control: A review. Int. Biodeterior. Biodegrad. 2009, 63, 959-972. [CrossRef]

30. Sakasegawa, M.; Hori, K.; Yatagai, M. Composition and antitermite activities of essential oils from Melaleuca species. J. Wood Sci. 2003, 49, 181-187. [CrossRef]

31. Park, I.L.K.; Shin, S.C. Fumigant activity of plant essential oils and components from garlic (Allium sativum) and clove bud (Eugenia caryophyllata) oils against the Japanese termite (Reticulitermes speratus Kolbe). J. Agric. Food Chem. 2005, 53, 4388-4392. [CrossRef] [PubMed]

32. Ramírez-López, C.B.; Beltrán-Sánchez, R.; Hernández-Izquierdo, A.; Salvador-Hernández, J.L.; Salcedo-Pérez, E.; Del Río, R.E.; Martínez Pacheco, M.M. Antifeedant activity of caesalpinia coriaria essential oil against Incisitermes marginipennis (Latreille). Phyton 2021, 90, 907-920. [CrossRef]

33. Zhang, H.; Chen, G.; Lü, S.; Zhang, L.; Guo, M. Insecticidal activities against Odontotermes formosanus and Plutella xylostella and corresponding constituents of tung meal from Vernicia fordii. Insects 2021, 12, 425. [CrossRef]

34. Mishra, T.; Gangoo, S.A.; Azad, A.; Kumar, A.; Pal, M. Chemical composition and antitermite activity of essential oil from Artemisia absinthium growing in Kashmir valley of India. J. Essent. Oil Bear. Plants 2020, 23, 397-404. [CrossRef]

35. Salem, M.Z.M.; Ali, M.F.; Mansour, M.M.A.; Ali, H.M.; Moneim, E.M.A.; Abdel-Megeed, A. Anti-termitic activity of three plant extracts, chlorpyrifos, and a bioagent compound (protecto) against termite Microcerotermes eugnathus silvestri (Blattodea: Termitidae) in Egypt. Insects 2020, 11, 756. [CrossRef]

36. Akbar, M.S.; Sajjad, F.; Afzal, M.; Luqman, M.; Riaz, M.A.; Majeed, M.Z. Field evaluation of promising botanical extracts, plant essential oils and differential chemistry insecticides against subterranean termites Odontotermes obesus (Isoptera: Termitidae). Sarhad J. Agric. 2021, 37, 120-127. [CrossRef]

37. Khanikor, B.; Barman, J.; Sarma, R.; Mahanta, S.; Adhikari, K. Evaluation of efficacy of three essential oils against Odontotermes feae (Isoptera: Termitidae). J. Environ. Pollut. Human Health 2018, 6, 68-76. [CrossRef]

38. Almeida, M.L.S.; Oliveira, A.S.; Rodrigues, A.A.; Carvalho, G.S.; Silva, L.B.; Lago, J.H.G.; Casarin, F.E. Antitermitic activity of plant essential oils and their major constituents against termite Heterotermes sulcatus (Isoptera: Rhinotermitidae). J. Med. Plants Res. 2015, 9, 97-103. [CrossRef]

39. Manzoor, F.; Asma Malik, S.; Naz, N.; Naz, S. Potential of antitermitic activities of eucalyptus oil. Pak. J. Zool. $2012,44,2$.

40. Maistrello, L.; Laine, R.A. Nootkatone is a repellent for formosan subterranean termite (Coptotermes formosanus). Artic. J. Chem. Ecol. 2001, 27, 523-531. [CrossRef]

41. Isman, M.B. Botanical insecticides, deterrents, and repellents in modern agriculture and an increasingly regulated world. Annu. Rev. Entomol. 2006, 51, 45-66. [CrossRef] [PubMed]

42. Lima, R.K.; Cardoso, M.G.; Moraes, J.C.; Andrade, M.A.; Melo, B.A.; Rodrigues, V.G. Caracterização química e atividade inseticida do óleo essencial de Ageratum conyzoides l. sobre a lagarta-do-cartucho do milho Spodoptera frugiperda (smith, 1797) (Lepidoptera: Noctuidae). Biosci. J. 2010, 26, 1-5.

43. Anderson, M.J.; Whitcomb, P.J. RSM Simplified: Optimizing Processes Using Response Surface Methods for Design of Experiments; CRC Press: Boca Raton, FL, USA, 2016; ISBN 1315351722.

44. Jeirani, Z.; Jan, B.M.; Ali, B.S.; Noor, I.M.; See, C.H.; Saphanuchart, W. Prediction of water and oil percolation thresholds of a microemulsion by modeling of dynamic viscosity using response surface methodology. J. Ind. Eng. Chem. 2013, 19, 554-560. [CrossRef]

45. Stanley, H.; Ogbonna, C.; Abu, G. Exploration of one-factor rsm to optimize the concentration of organic fraction of municipal solid waste (OFMSW) for biogas production. Int. J. Waste Resour. 2017, 7, 1-12.

46. Crespo, Y.A.; Sánchez, L.R.B.; Quintana, Y.G.; Cabrera, A.S.T.; del Sol, A.B.; Mayancha, D.M.G. Evaluation of the synergistic effects of antioxidant activity on mixtures of the essential oil from Apium graveolens L., Thymus vulgaris L. and Coriandrum sativum L. using simplex-lattice design. Heliyon 2019, 5, e01942. [CrossRef] [PubMed]

47. Van den Dool, H. A generalization of the retention index system including linear temperature programmed gas-liquid partition chromatography. J. Chromatogr. A 1963, 11, 463-471. [CrossRef]

48. Adams, R.P. Identification of Essential Oil Components by Gas Chromatography/Mass Spectrometry; Allured Publishing Corporation: Carol Stream, IL, USA, 2007; Volume 456, ISBN 10-1932633219. 
49. De Saint Laumer, J.Y.; Cicchetti, E.; Merle, P.; Egger, J.; Chaintreau, A. Quantification in gas chromatography: Prediction of flame ionization detector response factors from combustion enthalpies and molecular structures. Anal. Chem. 2010, 82, 6457-6462. [CrossRef] [PubMed]

50. Tissot, E.; Rochat, S.; Debonneville, C.; Chaintreau, A. Rapid GC-FID quantification technique without authentic samples using predicted response factors. Flavour Fragr. J. 2012, 27, 290-296. [CrossRef]

51. Pal, M.; Kumar, R.; Tewari, S.K. Anti-termite activity of essential oil and its components from Myristica fragrans against Microcerotermes beesoni. J. Appl. Sci. Environ. Manag. 2011, 15, 559-561.

52. Bakaruddin, N.H.; Dieng, H.; Sulaiman, S.F.; Ab Majid, A.H. Evaluation of the toxicity and repellency of tropical plant extract against subterranean termites, Globitermes sulphureus and Coptotermes gestroi. Inf. Process. Agric. 2018, 5, 298-307. [CrossRef]

53. Arteaga-Crespo, Y.; Radice, M.; Bravo-Sanchez, L.R.; García-Quintana, Y.; Scalvenzi, L. Optimisation of ultrasound-assisted extraction of phenolic antioxidants from Ilex guayusa Loes. leaves using response surface methodology. Heliyon 2020, 6, e03043. [CrossRef]

54. Gupta, A.; Sharma, S.; Naik, S.N. Biopesticidal value of selected essential oils against pathogenic fungus, termites, and nematodes. Int. Biodeterior. Biodegrad. 2011, 65, 703-707. [CrossRef]

55. Maia, J.G.S.; Andrade, E.H.A.; Maria das Graças, B.Z. Aroma volatiles from two fruit varieties of jackfruit (Artocarpus heterophyllus Lam.). Food Chem. 2004, 85, 195-197. [CrossRef]

56. Chang, S.T.; Cheng, S.S. Antitermitic activity of leaf essential oils and components from Cinnamomum osmophleum. J. Agric. Food Chem. 2002, 50, 1389-1392. [CrossRef]

57. Cheng, S.S.; Wu, C.L.; Chang, H.T.; Kao, Y.T.; Chang, S.T. Antitermitic and antifungal activities of essential oil of Calocedrus formosana leaf and its composition. J. Chem. Ecol. 2004, 30, 1957-1967. [CrossRef] [PubMed]

58. Jain, N.; Sharma, M.; Joshi, S.C.; Kaushik, U. Chemical composition, toxicity and antidermatophytic activity of essential oil of Trachyspermum ammi. Indian J. Pharm. Sci. 2018, 80. [CrossRef]

59. Adams, R.P. Cedar wood oil-Analyses and properties. In Essential Oils and Waxes; Springer: Amsterdam, The Netherlands, 1991; pp. 159-173.

60. Lin, T.; Yin, H. The effects of Cinnamomum spp. oils on the control of the termite Coptotermes formosanus Shiraki. Bull. Taiwan For Res. Inst. 1995, 10, 459-464.

61. Zhu, B.C.R.; Henderson, G.; Chen, F.; Fei, H.; Laine, R.A. Evaluation of vetiver oil and seven insect-active essential oils against the Formosan subterranean termite. J. Chem. Ecol. 2001, 27, 1617-1625. [CrossRef]

62. Subekti, N. Toxicity of essential oils against termite Macrotermes gilvus Hagen (Blattodea: Termitidae). J. Phys. 2020, 1567, 32053. [CrossRef] 